\title{
Innovative educational environment as a factor in improving the quality of higher education
}

\author{
Mankus I., Darmosiuk V., Vasylieva L. \\ V.O. Sukhomlynskyi Mykolaiv National University, Mykolaiv, Ukraine
}

Received: 30.08 .2019

Accepted: 20.09 .2019

\begin{abstract}
In the article the technology of creation of innovative educational environment which provides realization of requirements of European integration of education, namely improvement of quality of higher education is offered. The conceptual basis of the proposed technology is the guiding principles of partnership pedagogy, STEM - education, competency and transdisciplinary approaches, technology-based personality-oriented learning. Specific examples explored an educational system that would contribute to the formation of flexibility of thinking, its originality, ability to pose the problem and find out the ways to solve it, the ability to create, improve and construct objects, the ability to work in a team and ensure competitiveness future professionals in the educational services market. The main research methods were: pedagogical experiment, pedagogical prediction, abstract-logical, graphic, methods of analysis and synthesis, analogies, comparison, mathematical modeling. One way to achieve the goal of the study was to realize the principle of the relationship between science and education by updating the content of science and mathematics education and its design. In the course of the research, the structure of the educational environment was developed, which ensures the improvement of the system of natural and mathematical education and significantly improves the quality of training of competitive specialists for the market of educational services. The core of the structure is a student-centered educational and practical center, which is provided by two laboratories: scientific-methodical and educational-scientific. The purpose and content of learning in such an environment is to acquire participants' relevant competencies and personal experience: oriented, active, creative, axiological. The authors reveal the nature and the role of each component of the training and practical center in the process of formation of specialists' basic competencies in accordance with European standards. The Elements of the developed innovative scientific infrastructure were introduced at the Faculty of Mechanics and Mathematics of the V.O. Sukhomlynskyi Mykolayiv National University and in the educational institutions that are partners of the project.

Key words: STEM - education, student-centered learning, STEM-platform.
\end{abstract}

\section{Інноваційне освітнє середовище як фактор підвищення якості вищої освіти}

\author{
Манькусь І. В., Дармосюк В. М., Васильєва Л. Я. \\ Миколаївський національний університет ім. В.О. Сухомлинського, Миколаїв, Україна
}

\begin{abstract}
Анотація. В статті запропонована технологія створення інноваційного освітнього середовища, яке забезпечує реалізацію вимог євроінтеграції освіти, а саме підвищення якості вищої освіти. Концептуальною основою запропонованої технології $є$ провідні принципи педагогіки партнерства, STEM - освіти, компетентнісного та трансдисциплінарного підходів, технології особистісно-орієнтованого навчання. На конкретних прикладах досліджувалася освітня система, яка сприяла б формуванню гнучкості мислення, його оригінальності, здатності до постановки проблеми та з'ясування шляхів її розв'язання, здатності до творчості, удосконалення та конструювання об'єктів, вміння працювати в команді та забезпечувала б конкурентоспроможність майбутніх фахівців на ринку освітніх послуг. Основними методами дослідження були: педагогічний експеримент, педагогічне прогнозування, абстрактно-логічний, графічний, методи аналізу та синтезу, аналогї̈, порівняння, математичне моделювання. Одним із шляхів досягнення мети дослідження стала реалізація принципу взаємозв'язків між наукою та освітою через осучаснення змісту природничо-математичної освіти та її дизайну. В ході дослідження розроблено структуру освітнього середовища, яке забезпечує удосконалення системи природничо-математичної освіти та значно підвищує якість підготовки конкуренто спроможних фахівців для
\end{abstract}

Corresponding Author: Darmosiuk Valentyna Mykolayivna. Tel. (0512)37-88-16. E-mail: darmosiuk@gmail.com V.O. Sukhomlynskyi Mykolayiv National University, Nikolska Street, 24, Mykolayiv, Ukraine, 54001.

Відповідальний автор: Дармосюк Валентина Миколаївна. Тел. (0512)37-88-16 . E-mail: darmosiuk@gmail.com Миколаївський національний університет ім. В.О. Сухомлинського, вул. Нікольська, 24, м. Миколаїв, Україна, 54001. 
ринку освітніх послуг. Ядром структури є студентоцентрований навчально-практичний центр, роботу якого забезпечують дві лабораторії: науково-методична та освітньо-наукова. Метою і змістом навчання у такому середовищі $€$ набуття учасниками відповідних компетенцій та особистісного досвіду: орієнтованого, діяльнісного, творчого, аксіологічного. Авторами розкрито сутність і роль кожного компоненту навчальнопрактичного центру у процесі формування основних компетентностей фахівців відповідно до європейських стандартів. Елементи розробленої інноваційної наукової інфрраструктури запроваджені на механікоматематичному факультеті Миколаївського національного університету ім. В.О. Сухомлинського та в освітніх закладах, які є партнерами проекту.

Ключові слова: STEM - освіта, студентоцентроване навчання, STEM - майданчик.

\title{
Инновационное образовательная среда как фактор повышения качества высшего образования
}

\author{
Манькусь И. В., Дармосюк В. Н., Васильева Л. Я. \\ Николаевский национальній университет им. В.А. Сухомлинского, Николаев, Украина
}

\begin{abstract}
Аннотация. В статье предложена технология создания инновационной образовательной среды, обеспечивающей реализацию требований евроинтеграции образования, а именно повышение качества высшего образования. Концептуальной основой предложенной технологии являются ведущие принципы педагогики партнерства, STEM - образования, компетентностного и трансдисциплинарного подходов, технологии личностно-ориентированного обучения. На конкретных примерах исследовалась образовательная система, которая способствовала бы формированию гибкости мышления, его оригинальности, способности к постановке проблемы и выяснения путей ее решения, способности к творчеству, совершенствование и конструирование объектов, умение работать в команде и обеспечивала бы конкурентоспособность будущих специалистов на рынке образовательных услуг. Основными методами исследования были: педагогический эксперимент, педагогическое прогнозирование, абстрактно-логический, графический, методы анализа и синтеза, аналогии, сравнения, математическое моделирование. Одним из путей достижения цели исследования стала реализация принципа взаимосвязей между наукой и образованием через осовременивание содержания естественно-математического образования и его дизайна. В ходе исследования разработана структура образовательной среды, обеспечивающей совершенствование системы естественно-математического образования и значительно повышает качество подготовки конкурентоспособности способных специалистов для рынка образовательных услуг. Ядром структуры является студентоцентрированый учебно-практический центр, работу которого обеспечивают две лаборатории: научно-методическая и образовательно-научная. Целью и содержанием обучения в такой среде является приобретение участниками соответствующих компетенций и личностного опыта: ориентированного, деятельностного, творческого, аксиологического. Авторами раскрыта сущность и роль каждого компонента учебно-практического центра в процессе формирования основных компетенций специалистов в соответствии с европейскими стандартами. Элементы разработанной инновационной научной инфраструктуры введены на механико-математическом факультете Николаевский национальный университет им. В.А. Сухомлинского и в образовательных учреждениях, которые являются партнерами проекта.
\end{abstract}

Ключевые слова: STEM - образование, студентоцентроване обучения, STEM - площадка.

\section{Bcmyn}

Реалізація державної політики з огляду на адаптацію України до Європейського освітнього простору сприяє впровадженню передового досвіду та інновацій в освітній діяльності набутих європейською спільнотою в сфері підвищення якості освіти.

Посилення розвитку науково-технічного напряму в навчально-методичній діяльності на всіх освітніх рівнях; створення науково-методичної бази для підвищення творчого потенціалу молоді та просресійної компетентності педагогічних працівників обумовлює необхідність використання інноваційних форм і методів освітньої діяльності.

Європейський простір вищої освіти визначає основні компетентності фрахівців, а саме: спілкування державною та іноземною мовами, математична грамотність, компетентності в природничих науках, уміння навчатися впродовж життя, соціальні і громадянські компетентності, підприємливість, загальнокультурна, екологічна грамотність і здорове життя мають гармонійно поєднуватися в освітніх середовищах будь-якого рівня і створювати основу самореалізації особистості як фрахівця і як громадянина. 
Європейські стандарти і рекомендації щодо забезпечення якості у вищій освіті визначають головні умови формування зазначених компетентностей: запровадження студентоцентрованого навчання i викладання, забезпечення умов і підтримки необхідних для досягнення студентами прогресу у своїй академічній кар'єрі, вмотивованість викладачів закладів вищої освіти (3ВО).

Формула якості освітньої діяльності ЗВО об'єднує дев'ять ключових компонентів основними із яких є: педагогіка, що ґрунтується на партнерстві, сучасне освітнє середовище, яке забезпечує необхідні умови, засоби і технології для навчання студентів та освітян не лише в приміщенні навчального закладу, а і за його межами, умотивований викладач, який матиме свободу для творчості і професійного розвитку, новий зміст освіти, заснований на формуванні компетентностей, потрібних для успішної самореалізації в суспільстві.

Новий зміст освіти відповідно вимагає урізноманітнення технологій освітнього простору, що означає зростання частки проектної, командної і групової діяльності. Різноманітні дидактичні проблеми інновацій в освітній діяльності щодо формування компетентностей майбутнього викладача знайшли відображення у працях педагогів - вчених і практиків [1-11]. Вони досліджують нові максимально ефективні технології освітньої діяльності результатом впровадження яких $\epsilon$ фрормування високо адаптованої творчої особистості. Починаючи з середини двохтисячних років у європейських країнах збільшилась кількість досліджень з проблем побудови освітнього середовища в контексті розвитку STEM - освіти.

Зарубіжний досвід впровадження STEM - освіти досліджували О. В. Бутурліна, І.П. Василашко, О.А. Коваленко, О. В. Сапрунова, Н.В. Сороко, С.В. Федоренко. В їхніх роботах наведені успішні приклади впровадження STEM - освіти в різних країнах світу та реалізація цього напрямку в Україні, а також розповсюдження в освітньому просторі України STEM - інновацій.

Результати чисельних дослідження вчених методистів [12-15], свідчать, що запровадження в освітні середовище інноваційних технологій є передумовою переходу від знаннєво - просвітницької парадигми освіти до парадигми продуктивної діяльності, коли студенти засвоюють не готовий досвід досліджень у природничо-математичній галузі, а беруть активну участь у самостійному вивченні та дослідженні проблем.

Мета роботи: висвітлення особливостей створення інноваційного освітнього середовища, яке являє собою розгалужену систему пошуку, розвитку, підтримки та супроводу обдарованої молоді на основі інновацій в методах і формах освітньої діяльності, поєднує змістову компоненту з технічною, математичною, художньою творчістю, використанням мультимедійних засобів навчання та фрізичним експериментом для формування навичок наукової діяльності, винахідництва та креативу майбутніх фахівців.

\section{II Матеріал і методи дослідження}

Новий зміст освіти вимагає відмову від авторитарного стилю організації діяльності освітнього середовища орієнтацію на демократизацію та гуманізацію освіти. Однією із значущих компонентів стратегії сучасної освіти стала орієнтація на активне навчання через організацію STEM-орієнтованого підходу, в якому акцент робиться на посилення уваги до вивчення фізики, хімії, біології, інформатики, математики. Різні види STEM-майданчиків забезпечують поєднання змістової компоненти з технічною, математичною, художньою творчістю, формування навичок наукової діяльності, винахідництва, креативу, що відповідає основним засадам Концепції нової української школи [16-17]. Технології майстер-класу та проектної діяльності сприяють формуванню професійних компетентностей майбутніх викладачів природничо-математичних дисциплін [18-19].

Одним із компонентів організації продуктивних видів діяльності $€$ створення при 3ВО студентоцентрованих навчально-практичних центрів [20].

Концептуальною основою створення інноваційного освітнього середовища $є$ Закон про вищу освіту (2014), Закон про освіту (2017), Концепція НУШ, всеукраїнський експеримент «Створення вітчизняної моделі авторської школи».

Змістовою складовою запропонованої технології $\epsilon$ моделювання природничо-математичної освіти на основі діючих освітніх стандартів в закладах вищої та середньої освіти. Процесуальною 
складовою технології є сукупність інноваційних фрорм та методів освітньої діяльності, які інтегруються в довгострокові соціально-наукові проекти.

В процесі дослідження використовувалась низка методів, серед яких педагогічний експеримент, педагогічне прогнозування, абстрактно-логічний; граффічний; методи аналізу та синтезу, аналогії, порівняння; математичне моделювання.

\section{III Результати}

На основі провідних принципів STEM-освіти, трансдисциплінарних підходів, технологій особистісно-орієнтованого навчання створено інноваційне освітнє середовище, структура якого представлена в таблиці 1.

Табл. 1. Структура освітнього середовища

\begin{tabular}{|c|c|}
\hline Навчально-практичний центр & Методи та форми \\
освітньої діяльності
\end{tabular}

Розкриємо сутність і роль кожного компоненту навчально-практичного центру у процесі формування основних компетентностей фахівців відповідно до європейських стандартів.

Університетські студії $€$ основним елементом інноваційної наукової структури, в яких розробляються освітні продукти для різнорівневих освітніх середовищ. Концептуальною основою діяльності студій $є$ поєднання академічної підготовки фахівця у ЗВО з технологічною, інженерною, математичною відповідно до вимог його кваліфікації на ринку праці.

Студія «Майстер-клас» розробляє тематичні майстер-класи для учнів 3ОШ та вчителів фізики і математики: «Закохані в фізику», «Атракціон міфів», «Перлини світу», «Кастинг професій», «Архітектурне бюро», «Детективне агентство» та інші $[16-17,19]$.

Студія освітніх проектів під керівництвом викладачів, розробляє освітні проекти для ЗОШ та інших освітніх установ. Проекти переможців презентуються на засіданнях методичних об'єднань вчителів фізики та математики, на курсах підвищення кваліфікації вчителів, а також впроваджуються в освітніх установах міста та області [17].

В студії інфрормаційно-комунікаційних технологій розробляються сайти освітніх проектів, персональні сайти вчителів фізики та математики, ведеться підготовка фрахівців по створенню навчальних фрільмів, анімованих роликів (у середовищі розробки 3D-графіки), анімованих проектів, 
побудованих на парадигмі об'єктно-орієнтованого програмування, фото колажів, мультимедійних підручників з фізики та астрономії, готуються до друку студентські наукові праці за результатами проведених наукових досліджень та їх впроваджень.

Студія «Füsis» презентує творчі роботи учасників - дослідників у номінаціях: наукове дослідження, ноу-хау, хобі. Серед наукових «родзинок» цієї студії: неньютонівська рідина, інтерференція на крилах бабки, електричний скат, жираф, який навчився використовувати закони статики для комфоортного проживання, явище «туманного Альбіону», вогняне торнадо та інші моделі та презентації.

Студія «+» пропонує презентацію ART- проектів, тренінги особистісного росту, експозицію творчих робіт.

Метою функціонування мережі інтерактивних майданчиків $є$ забезпечення різних видів освітньої діяльності, які відповідають вимогам Європейського стандарту якості освіти щодо створення інноваційного освітнього середовища на основі сучасних методів та форм освітньої діяльності.

Модернізація мережі інтерактивних майданчиків з метою розширення можливостей освітньої діяльності навчально-практичного центру і підвищення якості підготовки фрахівців не тільки в університеті, а й за його межами обумовила створення системи студій майстер-STEM.

Основою більшості досліджень цієї системи є моделювання, конструювання, робототехніка. Так наприклад: «Екзопланети і їх особливості», «Визначення оптимальної відстані між сідлом і кермом велосипеда для велосипедиста при участі в гонці», «Літній душ», «Теоретичне моделювання електропровідності полімерних електролітів» та інші. Завдання студії: осучаснення методів, засобів та форм навчального процесу у вищій школі, співпраця учасників проекту на майданчиках галереї, впровадження в освітні середовища розроблених освітніх продуктів, стимулювання творчого розвитку та самовдосконалення всіх учасників проекту: студентів ВН3 різних рівнів акредитації, викладачів, вчителів та учнів загальноосвітніх навчальних закладів (3Н3), городян міста та інших учасників проекту.

Ідея роботи системи студій майстер-STEM полягає в об'єднанні навколо науки творчих особистостей різних поколінь в контексті STEM та Art освіти.

Розроблені освітні продукти на основі проектних технологій впроваджуються в різнорівневі освітні середовища, так наприклад: «Галерея творчих особистостей» - відкритий освітній проект, який розроблений і впроваджується командою механіко-математичного факультету (інформація на сайтах http://sites.google.com/site/testfizua, http://mehmat.mk.ua).

Тренінгові майданчики інтерактивної галереї творчих особистостей сприяють популяризації науки як сфери діяльності особистості, оскільки презентують творчі особистості через їх наукові досягнення, вагомі внески у розвиток науки і техніки, відданість педагогічній справі. Співпраця учасників в галузі фізичного експерименту, осучаснення змісту і структури природничо-математичної освіти, інтегрованого навчання на інтерактивних майданчиках галереї $є$ однією із форм організації навчального процесу у 3BO.

Тренінговий майданчик «Видатні фрізики поруч» студії «Галерея творчих особистостей» презентує видатних фізиків через їх відкриття. Ідея - впізнай фізика за дослідами, відтвори його відкриття власноруч. Майданчик презентує понад 20 видатних фізиків, а саме: Ісаак Ньютон, Галілео Галілей, Архімед, Піфрагор, Отто фон Геріке, Ганс Християн Ерстед, Бенджамін Франклін, Майкл Фарадей, Емілій Християнович Ленц, Андре-Марі Ампер, Альберт Ейнштейн, Макс Карл Ернст Людвіг Планк, Християн Гюйгенс, Миколай Коперник, Рене Декарт, Лінус Бенедикт Торвальдс, Август Фердинанд Мьобіус, Нікола Тесла, Вільям Генрі Гейтс III, Даніель Бернуллі, Микола Єгорович Жуковський тощо.

Наприклад, відомий політик, просвітитель, вчений, фізик Бенджамін Франклін. Учасникам галереї пропонується впізнати вченого на стодоларовій купюрі та виконати дослід з колесом Франкліна. Цікаво знати, що вчений займався вимірюванням теплопровідності різних матеріалів, вивчав явища охолодження рідини при випаровуванні, досліджував поширення звуку у воді і повітрі і, до речі, ніколи не був президентом Америки. Саме перу цієї надзвичайно мудрої людини з величезним життєвим досвідом належать такі відомі крилаті фрази як «час - гроші», «не відкладай на завтра те, що можна зробити сьогодні», «один переїзд дорівнює трьом пожежам».

Учасники галереї, які виконали завдання по відтворенню фрізичного відкриття, а саме продемонстрували фрізичний експеримент із запропонованим обладнанням та впізнали вченого, отримують фішки переможця та переходять до інших експонатів тренінгового майданчика. 
Ефективність впровадження результатів роботи галереї підтверджується створенням проектівсупутників в освітніх закладах міста та області: ЗН3 №3, 3Н3 №18, Криничанський 3Н3 та інш. Явкинський 3Н3 Баштанського району отримав грант Євросоюзу на створення Галереї творчих особистостей для шкіл Баштанського району.

Різноманітна освітня діяльність системи студій майстер- STEM зацікавила провідні підприємства та організації Миколаївщини щодо залучення в їх структури конкурентоспроможних фахівців. Саме цим обумовлено створення в навчально-практичному центрі кластера соціального партнерства.

Кластер соціального партнерства створений з метою пошуку, розвитку і підтримки талановитої, обдарованої молоді та популяризації науки, як сфрери діяльності особистості. Кластер об'єднує управління сім'ї та молоді Миколаївської міської ради та провідні підприємства (ТОВ «Золотий колос», компанія ADDRIAN, дизайн-студія «Ход конем»), Миколаївський обласний інститут післядипломної педагогічної освіти, ВНЗ І-ІІ рівнів акредитації (Миколаївський будівельний коледж, Миколаївський політехнічний коледж, коледж Миколаївського національного університету імені В.О. Сухомлинського), центри дитячої та юнацької творчості (м. Миколаїв, м. Вознесенськ, смт. Доманівка) Творчу обдаровану молодь проекту з бажанням та наснагою підтримують Іванова Н.В. - голова постійної комісії Миколаївської обласної ради з питань культури, науки і освіти, сім'ї та молоді, спорту, директор ТОВ «Золотий колос», дизайн-студія «Ход конем» директор Заболотний О., Погорєлов Євген - автор проекту «Казки Погорєлова».

Реалізація ідеї проекту щодо впровадження інноваційних фрорм і методів освітньої діяльності центру визначила необхідність створення науково-методичної лабораторії.

Науково-методична лабораторія технологічної підготовки викладача природничо-математичних дисциплін $\epsilon$ однією $з$ наукових складових навчально-практичного центру. Колектив лабораторії досліджує проблеми осучаснення змісту і технологій природничо-математичної освіти. Результати досліджень обговорюються на постійно діючому міжвузівському семінарі «Питання удосконалення змісту і методики викладання природничо-математичних дисциплін в середній і вищій школі». Кафедра фізики та математики механіко-математичного факультету МНУ ім. В.О. Сухомлинського видає щорічний науково-методичний журнал, який має державну реєстрацію Міністерства юстиції України від 24.11.2016p. № 3348/5.

Розробка та впровадження освітніх продуктів (саморобне фізичне обладнання, діючі моделі механізмів, моделі фізичних явищ, майстер-класи, міні-проекти та ін.) в різнорівневі освітні середовища привела до необхідності створення у навчально-практичному центрі освітньо-наукової лабораторії «Крок до науки».

Колектив освітньо-наукової лабораторії «Крок до науки» розробляє та впроваджує освітні продукти в різнорівневі освітні середовища. За час роботи лабораторії отримано 12 свідоцтв про реєстрацію авторського права.

Зокрема проект «Цікава наука на вулицях міста», мета якого створення освітнього середовища, яке забезпечує пошук, розвиток та підтримку творчих та обдарованих особистостей через широку популяризацію природничо-математичних наук.

Реалізація поставленої мети здійснювалась шляхом розв'язання завдань проекту:

- осучаснення методів, засобів та фрорм навчального процесу у вищій школі відповідно до концепції STEM та Art освіти; освіти;

- впровадження у навчальний процес 3ВО та різнорівневі освітні середовища технологій STEM

- розробка та впровадження освітніх продуктів проекту на ринку освітніх послуг.

Робота навчально-практичного центру забезпечується тісною співпрацею команд проекту, тобто його цільових груп на засадах педагогіки партнерства.

Кожна цільова група проекту має свою мету і виконує відповідні завдання.

Команда викладачів 3ВО:

- здійснює моніторинг та періодичний перегляд програм, щоб гарантувати, що вони досягають поставлених цілей і відповідають потребам студентів і суспільства.

- керує університетськими студіями, в яких розробляються освітні продукти для різнорівневих освітніх середовищ, як результат співпраці учасників студій; 
- проводить діагностику освітніх середовищ;

- розробляє методичне забезпечення проекту;

- визначає роль кожного учасника в проекті;

Команда студентів:

Створюється відповідно до мотивів їх майбутньої професійної діяльності, прагнень та потреб на засадах студентоцентрованого навчання. Студентам пропонується працювати в університетській студії. Робота в студії передбачає проведення фундаментальних фізичних та математичних досліджень, розробку міні-проекту «Паркінг цікавої науки» і роботу «Галереї творчих особистостей». Кожен напрямок діяльності університетської студії передбачає розробку, створення і впровадження в різнорівневі освітні середовища відповідних освітніх продуктів, якість яких визначає рівень професійної майстерності майбутніх викладачів.

Команда вчителів 3Н3:

Співпрацює в проекті із студентами на основі технології STEM та Art освіти, основою яких $є$ поєднання науки, техніки, інженерії, математики та досвіду професіоналів різного рівня. Ефективним прийомом цієї співпраці є оцінка професіоналом високого рівня результатів діяльності починаючого фахівця. Співпраця студентів та вчителів здійснюється в університетській студії, на інтерактивних STEM-майданчиках та в творчому центрі «Молодіжна хвиля».

Команда учнів 3Н3:

Учні, в ході навчального процесу, залучаються до проектної діяльності на інтерактивних майданчиках проекту, а також співпрацюють із студентами в Хоббі-класі та в студіях «Еврика» та «Студії +».

\section{IV Обговорення}

Створене освітнє середовище проекту забезпечує формування і розвиток профресійної майстерності майбутніх фахівців, креативних особистостей, що обумовлено необхідністю формування у них ключових компетенцій в контексті STEM та Art освіти та вимог європейського освітнього простору.

Якісні показники проекту:

- Активізація пізнавальної, творчої активності учнів 3Н3, яка підтверджена проведенням VIII фестивалю «Молодіжна хвиля» на базі механіко-математичного факультету МНУ імені В.О. Сухомлинського та на відкритих майданчиках міста. На VIII фестивалі зареєструвалося понад 540 учасників, які працювали в 27 студіях, та на відкритих майданчиках міста. Учні, які приймали участь в роботі університетських студій стали переможцями обласного форуму юних шанувальників фізики та астрономії, на якому презентували свої творчі наробки та обласних олімпіад з фізики та математики.

- Підвищення рівня фундаментальної підготовки учасників проекту засвідчено результатами роботи студій: понад 200 учасників фестивалю науки стали номінантами і нагороджені грамотами, подяками, сувенірами та медалями фестивалю, цінними подарунками та грошовими винагородами від партнерів проекту. Провідні підприємства-партнери започаткували присвоєння почесних звань «Кращий майстер» для студентів та «Майбутній майстер» для учнів ЗНЗ. Вчителі 3Н3, які приймають участь в проекті в якості членів журі, мають можливість підвищити мотиваційну складову організації освітнього процесу при викладанні предмету, ознайомитися з практичними можливостями осучаснення змісту природничо-математичної освіти та підвищити рівень професійної підготовки (більшість вчителів використовують сертифікати, отримані в університетських студія при атестації на більш високу категорію). Серед вчителів, які активно працюють членами журі два переможці конкурсу «Вчитель року 2017» та лауреат Всеукраїнського конкурсу «Вчитель року 2017» в номінації «Фізика» (3 місце), а також переможець міського педагогічного конкурсу «Нове ім'я - 2018».

- Створення освітніх продуктів (саморобне фізичне обладнання, діючі моделі механізмів, моделі фізичних явищ, майстер-класи, міні-проекти та ін.), якість яких засвідчена результатами їх впроваджень в 3Н3 міст та області та у ЗВО І-ІІ рівнів акредитації.

- Результатами виробничої практики студентів, які підтверджують стрімку адаптацію майбутніх фахівців до роботи в різнорівневих освітніх середовищах, високий рівень сформованості професійних компетентностей, здатність до творчості та проектування освітніх середовищ. Більшість студентів за 
підсумками практики оцінені на відмінно та відзначені подяками та грамотами педагогічних колективів $3 \mathrm{H} 3$.

\section{V Висновки}

Розроблена структура освітнього середовища забезпечує удосконалення системи природничоматематичної освіти та значно підвищує якість підготовки конкуренто спроможних фахівців для ринку освітніх послуг. Ядром структури є студентноцентрований навчально-практичний центр, роботу якого забезпечують дві лабораторії: науково-методична та освітньо-наукова.

В центрі започатковано роботу п'яти університетських студій, в яких студентами створюються інноваційні освітні продукти з метою осучаснення та підвищення якості природничо-математичної освіти, а також запровадження інноваційних форм та методів освітньої діяльності. В університетських студіях запроваджуються ідеї педагога-новатора B.O. Сухомлинського та STEM-орієнтований підхід до здійснення освітньої діяльності. Студенти - майстри університетських студій забезпечують роботу мережі інтерактивних STEM- майданчиків в школах міста і області. «Молодіжна хвиля» двічі на рік дарує школярам та городянам міста свята цікавої науки. Центр провів вісім фестивалів творчості та науки, учасниками яких стало біля двох тисяч учнів міста і області.

Новизна наукового продукту обумовлюються Концепцією нової української школи, що відповідає принципам дитино центрованого навчання та принципам педагогіки-партнерства. Технологія створення інноваційного освітнього середовища на засадах STEM - орієнтованого підходу до навчання має наскрізний характер: Заклади вищої освіти (науковці, студенти), освітні заклади (вчителі, учні). Це $€$ суттєвою відмінністю від існуючих аналогів технологій освітньої діяльності.

Подальший напрямок досліджень по моделюванню інноваційного освітнього середовища буде спрямований на можливість впровадження інших підходів до її організації з залученням сучасних форм неформальної освіти та обов'язкове врахування потреб регіону.

\section{Бібліографрічні посилання}

1. Андрущенко В. П., Бондар В. І. Модернізація педагогічної освіти відповідно до викликів XXI століття / Науковий вісник Миколаївського державного університету імені В. О. Сухомлинського. Серія: Педагогічні науки. 2010. Випуск 1.28. С. 12-20.

2. Бібік Н. М. Переваги і ризики запровадження компетентнісного підходу в шкільній освіті / Український педагогічний журнал. 2015. № 1. С. 47-58.

3. Ватякіна H. STEM-освіта: етапи становлення в Україні / Інформ. зб. для директора шк. та завід. дит. сад. 2015. № 17 18 (41). C. 47-52.

4. Дичківська І. М. Інноваційні педагогічні технології : навч. посібник. К. : Академвидав, 2004. 352 с.

5. Авшенюк Н. М., Десятов Т. М., Дяченко Л. М., Постригач Н. О., Пуховська Л. П., Сулима О. В. Компетентнісний підхід до підготовки педагогів у зарубіжних країнах: теорія та практика : монографрія. Кіровоград : Імекс-ЛТД, 2014. 280 с.

6. Компетентнісний підхід у сучасній освіті: світовий досвід та українські перспективи: Бібліотека з освітньої політики / під заг. ред. О. В. Овчарук. К. : «К.І.С.», 2004. 112 с.

7. Побірченко Н. С. Компетентнісний підхід у вищій школі: теоретичний аспект / Освіта та педагогічна наука. 2012. № 3 (152). C. 24-31.

8. Тараненко І. Розвиток життєвої компетентності та соціальної інтеграції / Кроки до компетентності та інтеграції в суспільство. К. : Контекст, 2000. С. 37-40

9. Х Хоружа Л. Л. Компетентнісний підхід в освіті: ретроспективний погляд на розвиток ідеї / Педагогічна освіта : теорія і практика : збірник наукових праць. К. : КМПУ імені Б.Д. Грінченка, 2007. № 7. (Серія "Психологія. Педагогіка"). 202 с.

10. Сисоєва С. Особистісно зорієнтовані технології: метод проектів :підручник для директора. К. : Плеяди, 2005. №9-10. C. 25-28.

11. Сисоєва С. О., Соколова І. В. Теорія і практика вищої освіти : навч.посіб. Київ-Маріуполь, 2016. 338 с.

12. Величко С. П., Сірик Е. П. Основні аспекти створення концептуальної моделі діяльності викладача фізики у підготовці фахівців нефізичного профілю / Збірник наукових праць Кам'янець-Подільського національного університету ім. Івана Огієнка. Серія : Педагогічна. 2017. Випуск 23. С. 125-129.

13. Іваницький О. І. Формування інтегральної компетентності майбутнього вчителя фізики на засадах акмеологічного, контекстного та компетентністного підходів// Збірник наукових праць Кам'янець-Подільського національного університету ім. Івана Огієнка. Серія : Педагогічна. 2017. Вип. 23. С. 129-132.

14. Садовий М. І., Слюсаренко В. В., Трифонова О. М., Хомутенко М. В. Формування експериментально-орієнтованого навчального середовища вивчення фрізики / Science and Education a New Dimension. Pedagogy and Psychology. 2014. II(16). Issue 33. P. 79-84. URL: http://seanewdim.com/ uploads/3/4/5/1/34511564/ sadovyi_.._slyusarenko_v.v._ 
trifonova_o.m._khomutenko_v._the_formation_of_experimentally-oriented_learning_environment_in_studying_physics.pdf. (дата звернення 20.08.2019).

15. Шарко В.Д. Підготовка вчителів до компетентнісного орієнтованого навчання: технологічний аспект / Сборник научных трудов SWorld [научный журнал]. Одесса, 2015. С. 57-62.

16. Дінжос Р. В., Недбаєвська Л. С., Манькусь І. В. STЕМ-майданчики як компонент розвитку нової української школи / Питання удосконалення змісту і методики викладання природничо-математичних дисциплін у середній і вищій школі, 2018. № 24. C. 5-7.

17. Манькусь І. В., Недбаєвська Л. С., Дармосюк В. М. Впровадження STEM-майданчиків як сучасних освітніх середовищ у професійній діяльності вчителя / Фізико-математична освіта. 2019. Випуск 1(19). C. 130-134. DOI 10.31110/24131571-2019-019-1-020.

18. Манькусь І. В., Недбаєвська Л. С. Технологія майстер-класу джерело формування професійних компетентностей викладача / Витоки педагогічної майстерності. 2017. № 1. С. 229-233.

19. Недбаєвська Л. С., Манькусь І. В., Дінжос Р. В. Сучасний урок фізики в контексті STЕМ-освіти. Миколаїв : МНУ, 2017. $93 \mathrm{c}$.

20. Манькусь І. В., Недбаєвська Л. С., Дінжос Р. В. Підготовка фахівців в ЗВО: інновації в методах і формах / Науковий вісник Миколаївського національного університету імені В.О. Сухомлинського. Педагогічні науки. М., 2018. №3 (62), Tом 2. C. $199-205$.

\section{References}

1. Andrushenko, V. P. (2010). Modernizatsiia pedahohichnoi osvity vidpovidno do vyklykiv XXI stolittia. Scientific Bulletin of Mykolaiv State University Sukhomlinsky. Series pedagogical sciences, 1.28, 12-20. [in Ukrainian]

2. Bibik, N. M. (2015). Perevahy i ryzyky zaprovadzhennia kompetentnisnoho pidkhodu v shkilnii osvit, № 1, 47-58. [in Ukrainian].

3. Vatiakina, N. (2015). STEM-osvita: etapy` stanovlennya v Ukrayini [STEM-education: stages of formation in Ukraine]. Inform. zb. dlya dy' rektora shk. ta zavid. dy't. sad. Information compilation for the school principal and head of the kindergarten, 17 18 (41), 47-52 [in Ukrainian].

4. Dychkivska, I. M. (2004). Innovatsiini pedahohichni tekhnolohii. Akademvydav, Kyiv, Ukraine, 352. [in Ukrainian].

5. Avsheniuk, N. M., Desiatov, T. M., Diachenko, L. M., Postryhach, N. O., Pukhovska, L. P., Sulyma, O. V. (2014). Kompetentnisnyi pidkhid do pidhotovky pedahohiv u zarubizhnykh krainakh: teoriia ta praktyka. Imeks-LTD, Kirovohrad, Ukraine, 280. [in Ukrainian].

6. Ovcharuk, O.V. et all (2004). Kompetentnisnyi pidkhid u suchasnii osviti: svitovyi dosvid ta ukrainski perspektyvy: Biblioteka z osvitnoi polityky. «K.I.S.», Kyiv, 112. [in Ukrainian].

7. Pobirchenko, N. S. (2012). Kompetentnisnyi pidkhid u vyshchii shkoli: teoretychnyi aspect. Osvita ta pedahohichna nauka, 3 (152), 24-31. [in Ukrainian].

8. Taranenko, I. (2000). Rozvytok zhyttievoi kompetentnosti ta sotsialnoi intehratsii. Kroky do kompetentnosti ta intehratsii v suspilstvo. Kontekst., Kyiv, Ukraine, 37-40. [in Ukrainian].

9. Khoruzha, L. L. (2007). Kompetentnisnyi pidkhid v osviti: retrospektyvnyi pohliad na rozvytok idei. Pedahohichna osvita teoriia i praktyka : zbirnyk naukovykh prats (Seriia "Psykholohiia. Pedahohika"), № 7. KMPU imeni B.D. Hrinchenka, Kyiv, Ukraine, 202. [in Ukrainian]

10. Sysoieva, S. (2005). Osobystisno zoriientovani tekhnolohii: metod proektiv. Pidruchnyk dlia dyrektora. Pleiady, Kyiv, Ukraine, №9-10, 25-28. [in Ukrainian].

11. Sysoieva, S. O., Sokolova, I. V. (2016). Teoriia i praktyka vyshchoi osvity: navch.posib. Kyiv-Mariupol, 338. [in Ukrainian].

12. Velychko, S. P., Siryk, E. P. (2017). Osnovni aspekty stvorennia kontseptualnoi modeli diialnosti vykladacha fizyky u pidhotovtsi fakhivtsiv nefizychnoho profiliu. Zbirnyk naukovykh prats Kamianets-Podilskoho natsionalnoho universytetu im. Ivana Ohiienka. Seriia : Pedahohichna, 23, 125-129. [in Ukrainian].

13. Ivanytskyi, O. I. (2017). Formuvannia intehralnoi kompetentnosti maibutnoho vchytelia fizyky na zasadakh akmeolohichnoho, kontekstnoho ta kompetentnistnoho pidkhodiv. Zbirnyk naukovykh prats Kamianets-Podilskoho natsionalnoho universytetu im. Ivana Ohiienka. Seriia : Pedahohichna, 23, 129-132. [in Ukrainian].

14. Sadovyi, M. I., Sliusarenko, V. V., Tryfonova, O. M., Khomutenko, M. V. (2014). Formuvannia eksperymentalnooriientovanoho navchalnoho seredovyshcha vyvchennia fizyky. Science and Education a New Dimension. Pedagogy and Psychology, II(16), 33, 79-84. [in Ukrainian].

15. Sharko, V. D. (2015). Pidhotovka vchyteliv do kompetentnisnoho orientovanoho navchannia: tekhnolohichnyi aspect. Sbornyk nauchnykh trudov SWorld, 57-62. [in Ukrainian].

16. Dinzhos, R. V., Nedbaievska, L. S., Mankus, I. V. (2018). STEM-majdanchy'ky' yak komponent rozvy'tku novoyi ukrayins'koyi shkoly' [STEM platforms as a component of the development of a new Ukrainian school]. Py'tannya udoskonalennya zmistu i metody 'ky' vy'kladannya pry'rodny'cho-matematy'chny'x dy'scy' plin u serednij i vy shhij shkoli Issues of improving the content and teaching methods of natural and mathematical disciplines in secondary and high school, 24, 5-7 [in Ukraine].

17. Mankus, I. V., Nedbaievska, L. S., Darmosiyk, V. M. (2019). Vprovadzhennia STEM-maidanchykiv yak suchasnykh osvitnikh seredovyshch u profesiinii diialnosti vchytelia. Fizyko-matematychna osvita, 1(19), 130-134. DOI 10.31110/2413-1571-2019019-1-020. [in Ukrainian] 
18. Mankus, I. V., Nedbaievska, L. S. (2017). Texnologiya majster-klasu dzherelo formuvannya profesijny'x kompetentnostej vy'kladacha [The technology of the master class is the source of the formation of the professional competence of the teacher]. Vy' toky” pedagogichnoyi majsternosti - The sources of pedagogical skills, 1, 229-233. [in Ukrainian].

19. Mankus, I. V., Nedbaievska, L. S., Dinzhos, R. V. (2017). Suchasny'j urok fizy'ky' v konteksti STEM-osvity': navchal'ny’j posibny'k [A modern physics lesson in the context of STEM education]. MNU, Mykolayiv, Ukraine, 93. [in Ukrainian].

20. Mankus, I. V., Nedbaievska, L. S., Dinzhos, R. V. (2018). Pidhotovka fakhivtsiv v ZVO: innovatsii v metodakh i formakh. Naukovyi visnyk Mykolaivskoho natsionalnoho universytetu imeni V.O. Sukhomlynskoho. Pedahohichni nauky, 3 (62), Tom 2. 199-205. [in Ukrainian].

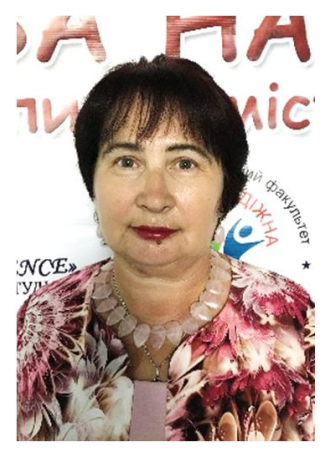

\section{Манькусь Ірина Володимирівна.}

Кандидат педагогічних наук, доцент, доцент кафедри фізики та математики,

Миколаївський національний університет ім. В.О. Сухомлинського,

вул. Нікольська, 24, м. Миколаїв, Україна, 54001.

Тел. (0512)37-88-16. E-mail: molodwave@gmail.com

\section{Mankus Iryna Volodymyrivna.}

Candidate of Pedagogical Sciences, Associate Professor, Associate Professor of Department of Physics and Mathematics, V.O. Sukhomlynskyi Mykolayiv National University,

Nikolska Street, 24, Mykolayiv, Ukraine, 54001.

Tel. (0512)37-88-16. E-mail: molodwave@gmail.com

\section{ORCID: 0000-0001-6118-4614}

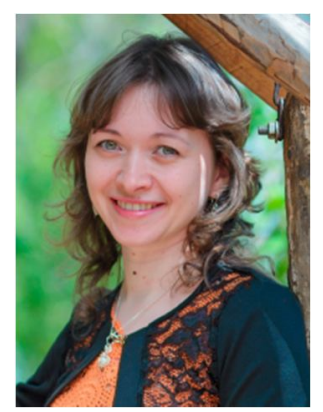

\section{Дармосюк Валентина Миколаївна.}

Кандидат фізико-математичних наук, старший викладач кафедри фізики та математики,

Миколаївський національний університет ім. В.О. Сухомлинського,

вул. Нікольська, 24, м. Миколаїв, Україна, 54001.

Тел. (0512)37-88-16 . E-mail: darmosiuk@gmail.com

\section{Darmosiuk Valentyna Mykolayivna.}

Candidate of physical and mathematical sciences, Senior Lecturer of Department of Physics and

Mathematics, V.O. Sukhomlynskyi Mykolayiv National University

Nikolska Street, 24, Mykolayiv, Ukraine, 54001.

Tel. (0512)37-88-16. E-mail: darmosiuk@gmail.com

ORCID: 0000-0003-3275-8249

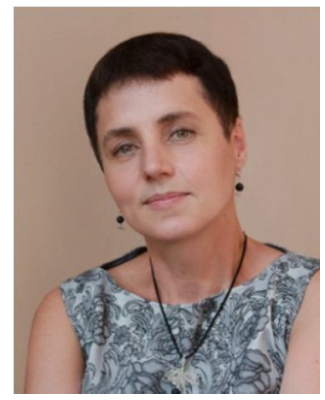

\section{Васильєва Лариса Яківна.}

Кандидат фізико-математичних наук, старший викладач кафедри фізики та математики,

Миколаївський національний університет ім. В.О. Сухомлинського,

вул. Нікольська, 24, м. Миколаїв, Україна, 54001.

Тел. (0512)37-88-16. E-mail: lara@vasiliev.mk.ua

\section{Vasylieva Larysa Yakivna.}

Candidate of physical and mathematical sciences, Senior Lecturer of Department of Physics and Mathematics, V.O. Sukhomlynskyi Mykolayiv National University

Nikolska Street, 24, Mykolayiv, Ukraine, 54001.

Tel. (0512)37-88-16. E-mail: lara@vasiliev.mk.ua

ORCID: 0000-0002-9046-6941

\section{Citation (APA):}

Mankus, I., Darmosiuk, V., Vasylieva, L. (2019). Innovative educational environment as a factor in improving the quality of higher education. Engineering and Educational Technologies, 7 (3), 40-49. doi: https://doi.org/10.30929/2307-9770.2019.07.03.04

\section{Цитування (ДСТУ 8302:2015):}

Манькусь І. В., Дармосюк В. М., Васильєва Л. Я. Інноваційне освітнє середовище як фрактор підвищення якості вищої освіти / Інженерні та освітні технології. 2019. Т. 7. № 3. С. 40-49. doi: https://doi.org/10.30929/2307-9770.2019.07.03.04

Обсяг статmі: $\quad$ сторінок-10; умовних друк. аркушів- 1,448. 